\title{
Overcrowding under the disciplinary umbrella: challenges of investigating and punishing sexual misconduct cases in universities
}

\author{
Elaine A.O. Freer" and Andrew D. Johnson
}

\begin{abstract}
The last year has seen a revolt against the recommendations of the Zellick Report (1994) in England and Wales, and pressure on universities worldwide to bring serious criminal conduct within their own disciplinary structures. This paper examines the reasons why the Zellick Report advised against this, and why higher-education institutions have now turned their back on a number of its recommendations. Factors including student pressure and concerns about low conviction rates for sexual offences in the criminal courts have been cited, but this paper argues that universities will struggle to create a disciplinary system that is fair to both those who are accused of such offences and those who have been victims of them. A recent Universities UK report has reversed the Zellick guidance that conduct amounting to a serious criminal offence should never be pursued under university disciplinary structures. Drawing on both authors' experiences as practitioners, and using the first author's experience of university disciplinary matters as a case-study, this paper reviews the practical problems of bringing such serious conduct under university disciplinary structures, focusing particularly on the intersection of criminal and internal disciplinary proceedings. It concludes by suggesting possible ways of ameliorating these.
\end{abstract}

\section{Introduction}

In I992, AD was a student at King's College London (KCL). He was accused of rape by another student (Ms X). AD maintained that the sexual intercourse was consensual. Contrary to KCL's advice and requests, Ms X did not report the matter to the police. Instead, she asked for the matter to be dealt with by KCL's internal disciplinary committee. AD eventually reported the case to the police because he felt that the charge was too serious for a disciplinary committee to rule upon, and consequently lacked confidence in KCL's disciplinary committee's ability to consider it (Midgley, I 994).

KCL suspended $\mathrm{AD}$ as a result of the allegation. He was prosecuted by the state, and was acquitted by unanimous verdict at trial. A subsequent inquiry concluded that the alleged offence was so serious that KCL should have taken independent legal advice and promptly referred the matter to the police. AD brought a successful civil claim against KCL for their decision to suspend him, and was awarded significant damages (NUS, 2015, p. 3).

Unease about the case of AD led to the Zellick Report, which was published in I994. In summary, that report recommended that universities never deal with behaviour amounting to serious criminal offences (i.e. those triable only on indictment, or for which conviction is likely to lead to a custodial sentence) under their own disciplinary structures, but advise students to report such matters to the

* Barrister, 5 Paper Buildings (Chambers of Miranda Moore Q.C. and Julian Christopher Q.C.) and College Teaching Officer, Robinson College, University of Cambridge). E-mail: ef269@cam.ac.uk.

** Barrister, 5 Paper Buildings (Chambers of Miranda Moore Q.C. and Julian Christopher Q.C.). The authors are grateful to two anonymous reviewers for their comments on earlier drafts. The first author is grateful to various colleagues who offered helpful comments on earlier drafts. 
police for criminal proceedings to be brought if the police and Crown Prosecution Service (CPS) decide there is sufficient evidence and it is in the public interest to do so (Zellick Report, I994, p. 9). It contained a number of recommendations to higher-education institutions that were widely implemented and followed, although not binding. Notably, it acknowledged that the permissible scope of disciplinary authority was unclear, and that Codes of Student Discipline were often ambiguous, leaving much to the discretion of those who operated them (Zellick Report, I994, p. 5). This has been borne out in the experience of the first author (X) over twenty years later.

The Zellick Report explored the demarcation between those matters suitable for investigation by a university's internal disciplinary procedure and those that should be subject to police investigation. The report acknowledged that all universities should be permitted to deal with misconduct in the student community, even if it amounted to criminal conduct (Zellick Report, I994, p. 8). However, Zellick argued that serious offences (defined as above) should not be within universities' internal disciplinary remits:

'At the other end of the spectrum are offences of such seriousness that substantive internal action prior to police investigation is out of the question. Allegations of rape and other sexual assaults ... are examples of cases that must be investigated by the police and considered by the prosecuting authorities before they can be handled internally, even if the student suspect or the victim/ complainant or both express a strong preference for the matter to be dealt with internally. The disciplinary process may be instituted but should then be deferred, except for the possibility of suspension or exclusion.' (Zellick Report, I994, paragraph I2)

For the reasons we set out below, we argue that this demarcation, between matters that can and should be dealt with internally and those that require a specialist procedure, through police investigation and criminal prosecution, was a sensible one.

The report continued that, even where the accused student admitted the allegation, the matter should go to the police, as there might remain factual conflict relevant to penalty (such as a Newton hearing would resolve in criminal proceedings; Zellick Report, I994, paragraph I3). ${ }^{\text {I }}$ Where a complainant refused to report the matter to the police, the report stated that universities should not use their internal procedures (Zellick Report, I994, paragraph I4). If a decision was taken by the police not to prosecute, then universities were advised to proceed only exceptionally and where it was clear that the police or CPS decision was based on some special factor separate from the quality of the evidence (Zellick Report, I994, paragraph I5). This avoided the doublejeopardy effect - criminal and disciplinary proceedings on exactly the same facts for very similar 'offences'.

Different issues arose where the complainant expressly did not wish for police involvement, with the guidance saying that 'only in exceptional circumstances should the university report an alleged crime to the police contrary to the wishes of the victim' (Zellick Report, I994, paragraph 22).

The report acknowledges that there will be exceptional situations in which it is appropriate for the university to report the allegation due to public interest factors, including the interests of the university community, such as the use of significant violence or repeated similar allegations (Zellick Report, I994, p. II, paragraph 22). It also points out that universities should encourage reporting to the police with no consideration to whether there will be damage to the university's reputation as a result of the report (Zellick Report, I994, paragraph 23). There is merit in this argument. Considering that many victims of sexual misconduct feel that the commission of the

I (I982) 4 Cr. App. R. (S.) 388; this case provides that, where a defendant pleads guilty to an offence but not on the facts as alleged by the Crown and that difference will make a material difference to the sentence, evidence will be heard to resolve the difference in accounts between the Crown and the defence. 
offence has overridden their free will, to then further have their choice not to report the matter disregarded might cause additional distress.

The writers of the Zellick Report declined to produce a 'Model Code' for dealing with such matters, though they did produce 'Model Clauses' in Appendix IV to the report (Zellick Report, I994, pp. 22-23). The model clause states that suspension (exclusion from all university premises and activities) should be used only where exclusion (from certain areas or activities) is inadequate. The report furthermore states that any such decision should not be taken lightly, and should be taken at the highest level within the university and subject to periodic review (presumably by that person, although this is not made explicit) (Zellick Report, I994, paragraph 28). Such serious circumstances clearly require this close monitoring for fairness to both parties. As a police investigation progresses, more or clearer information may become available that influences whether the accused student is thought to be a wider risk. If criminal proceedings have led to a charge, bail conditions are likely to restrict possible contact between defendant and complainant anyway.

Where criminal charges have been brought and proceed to trial, the report noted that later disciplinary proceedings must not be a rerun of the trial (Zellick Report, I994, paragraph 3I). Furthermore, the university must consider whether it is really necessary to proceed with disciplinary proceedings after a trial (Zellick Report, I994, paragraph 32). The report gives as an example that, where a student has been acquitted of rape, the university should not pursue a complaint of rape, sexual assault or harassment closely associated. However, where there is an acquittal for actual bodily harm, for example, if property damage was caused in the same incident, that could be pursued (Zellick Report, I994, paragraph 33). Regrettably, this does not prevent, for example, the university pursuing a vague, or more widely drafted charge, which encompasses some or all of the behaviour amounting to the criminal offence along with other behaviour that does not amount to a criminal offence.

This is not a suggestion that universities cannot proceed to take internal disciplinary action once a trial has concluded, but that any penalty imposed by the university should take into consideration the outcome of the trial and the punishment (if convicted) already imposed by the court. Such guidance is in line with the recommendation of an inquiry conducted after AD's case by Judge Marcus Edward that the university must be particularly careful about proceeding after a trial, especially regarding 'seek[ing] to look behind the verdict' (Midgley, I994).

In light of the recommendations of the Zellick Report, it has been usual practice for the last twenty years for universities to address non-criminal student misbehaviour, such as cheating in exams or plagiarism, through internal disciplinary structures. Behaviour also potentially amounting to a criminal offence, however, is usually outwith university disciplinary structures, with students advised to report the matter to police. Should they choose not to do so, it seems that most universities viewed this lack of reporting as either an indication that the victim did not want to pursue the matter at all or that it was simply not the university's business to proceed in such circumstances. What the Zellick Report's recommendations crucially avoided was the risk that criminal and disciplinary proceedings would collide - something we argue is a concern that is now being unacceptably under-estimated.

As societal awareness of the complexities of sexual offence cases and especially victim-reporting decisions, both statistically ${ }^{2}$ and academically (Fisher et al., 2003), increases, universities have come under increasing pressure to 'take action'. Such pressure is increased by high levels of publicity when

2 Overview of Violent Crime and Sexual Offences. London: Office for National Statistics. Available at: <http://www. ons.gov.uk/peoplepopulationandcommunity/crimeandjustice/compendium/focusonviolentcrimeandsexual offences/yearendingmarch20I5/chapterioverviewofviolentcrimeandsexualoffences> (accessed 2 November 2017). 
the criminal justice system is perceived as failing victims of sexual misconduct in universities, such as in the much-reported 2016 events at Stanford University. ${ }^{3}$ The result has been pressure to bring even behaviour that could amount to very serious criminal offences, including rape, under their disciplinary auspices, not just in the UK, but in other countries, most notably the US, as well.4

2016 saw a number of relevant events in the US: the announcement by Florida State University (FSU) that it would settle with former student Erica Kinsman, who was bringing a Title IX lawsuit against the university, despite findings in a student conduct hearing that absolved FSU. 5 The trial of Brock Turner, the Stanford University student who was prosecuted, and convicted, through the criminal process, of drunkenly raping an unconscious young woman visiting her sister on campus, put the international spotlight on how universities deal with such cases. Some commentators noted that Title IX, requiring campus codes of conduct to include policies on sexual assault, was a fair way of ensuring that sexual misconduct on campus is punished, and that the 'preponderance of evidence' test used in university misconduct proceedings was appropriate when considering that the penalties available are much less. ${ }^{6}$ Others, with whom we agree, argued that universities were simply the wrong settings for such allegations to be determined. ${ }^{7}$ In September 2017, the Secretary of Education announced a review of guidance issued by the Obama administration, ${ }^{8}$ indicating her intention was to rescind it, criticising the lack of due process.

\subsection{Students revolt against Zellick guidelines}

Much of this pressure has come from students themselves. In 2015, the NUS asked its members whether the guidance formulated in the Zellick Report was 'fit for purpose in 2015'. In its briefing document (NUS, 2015), the NUS suggested that there were five particular issues with the Zellick guidance. First, the report was out of date, especially in light of new legislation. It was suggested that it was potentially in breach of the Equality Act 2010 and the Human Rights Act I998, and sat uncomfortably with the 2005 creation of the Office of the Independent Adjudicator, who deals with student complaints about higher education.

Second, the NUS argued that Zellick guidance represented an insufficient response by universities to acts of sexual violence. The briefing document states that:

'This is concerning as it demonstrates a lack of understanding as to the nature of sexual violence and assault cases within the criminal justice system. Evidence shows that $82 \%$ of rapes are never reported to the police and of these, only I in 5 results in court proceedings. For the few cases which do enter the court system, the average length of the court process is I year and 4 months from report to verdict - at which point many victims may no longer be studying at the university.' (NUS, 20I5, p. 3)

3 Available at: 〈https://www.theguardian.com/us-news/20i6/jun/I I/stanford-sexual-assault-students-plangraduation-protest-as-anger-grows $>$ (accessed 2 November 2017).

4 Available at: 〈https:/www.nytimes.com/2017/02/I8/us/college-campuses-title-ix-sexual-assault.html?_r=0〉 (accessed 2 November 2017).

5 Available at: 〈https://unicomm.fsu.edu/statements/fsu-announces-settlement-in-erica-kinsman-matter/〉 (accessed 2 November 2017).

6 Available at <https:/www.nytimes.com/2017/08/03/opinion/weakening-college-sex-assault-policies.html? emc=etaI $>$ (accessed 2 November 20I7).

7 Available at: <http://www.nationalreview.com/article/450 I7 I/campus-rape-allegations-courts-not-schoolsare-best-judge > (accessed 2 November 2017).

8 Available at: 〈http://edition.cnn.com/2017/og/o7/politics/betsy-devos-education-department-title-ix/index. html> (accessed 2 November 2017). 
Third, the Zellick Report did not, in the view of the NUS briefing, properly balance the rights of the accused with those of the victim - the clear implication being that there were 'too many' rights for the accused when the university left them to be dealt with by state proceedings:

'The Zellick Report's guidance is ultimately an attempt to ensure that a HEI is not subject to prosecution for an unfair decision made to a student who is subsequently acquitted of a criminal offence (as in [AD's] case where the student was suspended but not convicted of rape). However, to what extent does this ignore the rights of the victim and the universities' duty of care towards a student who has been subject to any form of harassment or violence? In the Zellick Report there is little focus on the rights of the victim or the universities' accountability to survivors (including information on how victims can access support ...).' (NUS, 20I5, p. 4)

Fourth, adherence to the Zellick guidance was argued to fail to create a safe environment for students:

'They are potentially exposed to further incidents of sexual violence by the same perpetrator if s/ he is allowed to continue to access universities services (including university accommodation services). Since it is highly likely that the perpetrator is known to the victim, it is also likely the student will come into contact with them again. ... In addition, if disciplinary procedures are not invoked this may put other students at risk, particularly as there is evidence that a perpetrator is likely to be a repeat offender.' (NUS, 20I5, p. 4)

Fifth and finally, it was argued by the NUS that the Zellick guidance did not provide specific guidance on how universities should respond to complaints of sexual offences or what pastoral support might be needed by victims during the reporting process. Therefore, as part of its 2015 Women's Campaign 'Stand By Me', the NUS asked students to consider through the lens of these questions whether the Zellick Report was fit for purpose:

- 'If the Zellick report isn't fit for purpose, how do we improve the reporting systems in place to support victims of sexual violence?

- What disciplinary procedures should we enact for perpetrators of violence and when?

- Should universities do more or is the problem really located in our criminal justice system which fails to adequately respond and address cases of sexual violence?

- How can the university play a part in supporting the police to carry out its investigations?' (NUS, 2015, p. 5)

This coincided with a review by Universities UK. They established a taskforce on violence against women, harassment and hate crime. The remit for this taskforce was set as 'to explore what more can be done to support the higher education sector to prevent and respond to incidents of violence and sexual harassment against women, hate crimes and other forms of harassment' (Universities UK, 20I5, p. ). ${ }^{9}$ The taskforce has subsequently met a further two times, publishing progress reports on both occasions. ${ }^{\text {IO }}$ In 20I6, Universities UK published its final report: 'Changing the Culture', making recommendations based on the work of the taskforce.

9 Available at: <http://www.universitiesuk.ac.uk/policy-and-analysis/reports/Documents/20I6/harassmenttaskforce-progress-report-I.pdf> (accessed 2 November 2017).

Io Available at: <http://www.universitiesuk.ac.uk/policy-and-analysis/reports/Documents/20I6/harassmenttaskforce-progress-report-2.pdf〉 (accessed 2 November 2017); 〈http://www.universitiesuk.ac.uk/policy-andanalysis/reports/Documents/20I6/harassment-taskforce-progress-report-3.pdf $>$ (accessed 2 November 20I7). 
Anecdotally, students welcomed the decision to bring matters under the disciplinary umbrella (Upham, 20I5), although others pointed out that a policy change did not equate to the shift in culture necessary to tackle such matters, and also questioned how the policy would work in practice (albeit from a complainant standpoint - there was a notable lack of any concern for accused students) (Horgan, 20I5). We argue that this lack of concern for accused students represents a manifestation of a 'guilty as soon as charged' mindset that is not conducive to fair proceedings. Regrettably, it is manifested in the disciplinary offences that some universities created in response to the Universities UK report.

\section{Move towards bringing criminal offences under university disciplinary structures}

The outcome of these two movements was greater scrutiny of what universities were doing when sexual misconduct was alleged between university members. This scrutiny was not confined to students, spilling into the national press, with The Guardian reporting on university procedures for reporting and recording sexual allegations between students (McVeigh and Cresci, 2015). One Oxford University student, Elizabeth Ramey, waived her anonymity and sued the university, ${ }^{\mathrm{II}}$ alleging that she had not received an appropriate response when she reported a sexual assault (Bowcott, 20I5). She had initially complained through internal procedures that the university failed to properly investigate the allegation or punish the alleged perpetrator. Dissatisfied with the response, she took her complaint to the Office of the Independent Adjudicator of Higher Education (OIA).

The OIA partially upheld the complaint, recommending clarification and amendment of Oxford's policies. Ms Ramey took her complaint to the High Court, supported by the Equality and Human Rights Commission. She sought judicial review of Oxford's policies, alleging that the university was indirectly discriminating against women by creating a hostile environment and a substantial risk of the violation of women's rights if allegations are not investigated (Goldhill and Ward, 20I5). The basis of this allegation was that Oxford's own policies allowed it to avoid investigating and punishing sexual misconduct allegations. Ms Ramey's challenge was unsuccessful: Mr Edis J. refused her renewed application (her application had originally been refused on the papers by McGowan J.), as she was no longer a student at the university and consequently lacked standing to bring a claim, and also that the policy that she sought to have reviewed had never been applied to her, it being an updated version of the policy in place in 20 I I when she had made a complaint.

Despite this, many universities made the move towards bringing such matters under their disciplinary policies, especially those Russell Group universities who were criticised in the The Guardian report (McVeigh and Cresci, 20I5). Cambridge was amongst these, introducing into its Statutes and Ordinances a new Regulation 6 by Grace 6 on I 5 July 2015 (Statutes of the University of Cambridge, Chapter II, 20I5, p. I94). Regulation 6 reads:

'No member of the University shall engage in harassment in the course of an academic, sporting, social, cultural, or other activity either within the Precincts of the University or elsewhere in the context of her or his membership of the University or in circumstances where the victim of the harassment is a member, officer, or employee of the University or a College. Harassment shall include single or repeated incidents involving unwanted and unwarranted conduct towards another person which is reasonably likely to have the effect of (i) violating that other's dignity

I I $R$ (Ramey) v. Oxford University [20I4] EWHC 4847 (Admin). 
or (ii) creating an intimidating, hostile, degrading, humiliating, or offensive environment for that

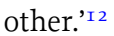

In the summer of 2016, the first author was asked to represent a student in the first disciplinary investigation into harassment under Regulation 6 at Cambridge University, where she is a member of the panel available to represent students in any internal disciplinary matters. The authors were musing in chambers on the consequences of universities bringing disciplinary action on facts traditionally reserved to criminal proceedings, and decided a closer examination of the issue was worthwhile. This was reinforced as the proceedings continued after the police had decided to take no further action in the matter, although ultimately no charges were brought by the University Advocate (UA) either. As a result, the main analysis in this paper comes from our combined professional interests and experiences, ${ }^{\mathrm{I}}{ }^{3}$ and is done by way of comparison between criminal proceedings for harassment and sexual misconduct, and their counterpart proceedings under internal disciplinary structures. Occasional comparisons are drawn with other universities, but space precludes a detailed examination of this, as it does a comparison to the situation seen in American universities, where these matters have also been headline news recently.

\section{Structure of disciplinary processes in universities}

Universities have traditionally dealt with academic misconduct through their disciplinary systems. Plagiarising dissertations, cheating in exams and handing in coursework under one student's name when more had contributed all fell squarely under the remit of university disciplinary processes. At Cambridge, it is Statute D of the University Statutes and Ordinances that governs disciplinary matters. Chapter I of this statute begins:

'I. There shall be a court called the University Tribunal, and a court called the Septemviri, which shall be constituted by Special Ordinance. These courts shall have no jurisdiction over the Chancellor, the High Steward, the Deputy High Steward, or the Commissary.

2. The University Tribunal shall adjudicate, in accordance with the provisions of this Statute, when a University officer, a member of the Senate, or a person not in statu pupillari who holds either a degree or the title of a degree is charged with an offence against the discipline of the University, or with grave misconduct, save that a University disciplinary panel established under Section ro shall adjudicate where all offences are alleged to have been

I 2 Since this article was accepted for publication, Reg. 6 has been amended, with effect from 4 August 20I 7. The amended version reads:

'6. (a) No member of the University shall engage in the harassment of:

(i) a member, officer, or employee of the University or a College; or

(ii) any other person where the harassment takes place either within the Precincts of the University or in the course of a University or College activity.

(b) Harassment shall include single or repeated incidents involving unwanted and unwarranted conduct towards another person which is reasonably likely to have the effect of (i) violating that other's dignity or (ii) creating an intimidating, hostile, degrading, humiliating, or offensive environment for that other.'

This change does not apply retrospectively.

I3 The second author was called in 2008 and now has a mixed practice, prosecuting and defending in both criminal and regulatory matters. The first author has been a tenant since October 20I6; she is also a parttime College Teaching Officer at Robinson College, University of Cambridge, and is on the panel of defence advocates for university disciplinary matters. 
committed during the period in which that person was pursuing a course of study leading to the award of a degree, diploma, or certificate of the University.'

This makes it clear that, for the most part, it will be a university disciplinary panel (UDP) that deals with allegations of sexual misconduct against a current student of the university. Reading a little further makes clear the extent of the unfettered power that UDPs have:

'There shall be such University disciplinary panels for the regulation of student discipline as shall be determined by Special Ordinance. These panels shall have no jurisdiction over the Chancellor, the High Steward, the Deputy High Steward, or the Commissary. Such panels shall have power to make rules of procedure except in so far as such rules may have been determined by Statute or Ordinance; provided that, if any question of law or interpretation or application of any of the rules of procedure arises during the course of a hearing, or if a question of procedure arises which cannot be resolved by reference to those rules, the matter shall be decided by the Chair, whose decision shall, for the case which is being heard, be final.' (2015, p. 32, paragraph I0)

Procedurally, the statute is sparse, simply saying that any person whose case is being heard or adjudicated upon by a UDP shall be given a reasonable opportunity of being heard by the UDP (Statute D, Chapter 2, p. 32, paragraph I3) and shall have the right to call witnesses upon whose evidence the case against them is based (except on appeal, where recall will only be permitted if the Chair judges it necessary or expedient in the interests of justice to do so, which mirrors the approach of the High Court to appeals from professional disciplinary bodies such as the General Medical Council). ${ }^{\mathrm{I}}$ The statute then continues:

'Notwithstanding the provisions of Section I3 of this chapter, any disciplinary panel established under Section Io may conduct the whole or part of its proceedings on the basis of written statements submitted by the parties and the Septemviri and the University Tribunal may, if or to the extent that it appears to the Chair to be impracticable to conduct an oral hearing, proceed likewise.' (2015, p. 32, paragraph I4)

Furthermore, whilst the statute expressly states that institution of proceedings outside of the university disciplinary structure does not affect the exercise of university disciplinary powers, it wholly fails to consider how the two might interact - a fact that the writers find deeply concerning for reasons set out in full below:

'the fact that any person has been or is liable to be prosecuted in a court of law in respect of an act or conduct which is the subject of the proceedings before them shall not affect the jurisdiction and powers of the Septemviri, the University Tribunal, or any disciplinary panel established under Section Io of this Statute.' (2015, p. 33, paragraph I6)

The broad requirements of university statutes are enlarged upon in greater detail by Special Ordinance. For the purposes of this paper, the relevant disciplinary provisions are contained within Special Ordinance D (II). ${ }^{15}$ Pursuant to Statute D, the university has established by Special Ordinance a single UDP known as the disciplinary committee (DC):

I4 See Rule 52.II(2)(a) of the Civil Procedure Rules I998, and see also Priess v. The General Dental Council [200I] UKPC 36, at [26], Moeska v. Nursing and Midwifery Council [2014] EWHC 846 (Admin).

I5 Available at:〈http://www.admin.cam.ac.uk/univ/so/20I5/special_d-sectionı.html〉 (accessed 2 November 2017). 
'As a body hearing a case at first instance the Discipline Committee shall, subject to the provisions of this Special Ordinance, adjudicate when any person in statu pupillari ... is charged with a breach of the general regulations for discipline or other offence against the discipline of the University.' (2015, pp. 96-97, paragraph 3)

The Special Ordinance contemplates the prospect of a person being prosecuted in respect of matters that bring them before a DC, setting out that:

'If any person has been or is liable to be prosecuted in a court of law in respect of an act or conduct which is the subject of proceedings before a University disciplinary panel, the proceedings of that panel may, at the discretion of the Chair of the panel, be stayed until the court proceedings in respect of that act or conduct have concluded, whether by conviction, acquittal or discontinuance of proceedings, or the Chair of the panel is satisfied that the person is not likely to be prosecuted.' (20I5, p. 98, paragraph II)

Once again, in our view, it is inappropriate for the determination of whether proceedings be stayed to be subject to the seemingly unfettered discretion of the Chair. Save where the respondent to the proceedings requests it, is it difficult to see how it could ever be appropriate to proceed with a disciplinary hearing prior to the conclusion (or abandonment) of a criminal prosecution.

On 22 December 2016, the University of Cambridge withdrew a Grace that would have created a new procedure for dealing with complaints of harassment under Regulation 6. Opposed by members of the defence panel, this was withdrawn by the vice chancellor before it passed automatically. ${ }^{\mathrm{I}} 6$ A new Grace, amended in consultation with the panel, led to the incorporation of safeguards, the main amongst which were greater clarity for accused students about the nature of the charge being investigated; the possibility of anything said being used in subsequent criminal proceedings; and clear advice that support from the panel of defence advocates is available.

These changes were discussed and agreed in the Second Joint Report of the Council and the General Board on the consideration of student complaints of harassment and sexual misconduct, as reported in the University Reporter of 25 January 2017:

'Consequently, small but important changes have been made to the original wording of section 5 of the proposed new Special Ordinance D (v) and to subparagraphs 6.2.3 and 6.2.4 of the proposed Procedure for Handling Cases of Student Harassment and Sexual Misconduct, as set out at Annex I of the first Report, together with consequential amendments to the Explanatory Notes and their appendix at Annex II.

These changes require a person who is invited to submit representations regarding the imposition of precautionary measures under the proposed Special Ordinance, or who is the subject of a complaint under the proposed Procedure, to be warned that any admissions made by that person may be used as evidence in any subsequent criminal investigation or proceedings in a court of law or in University disciplinary proceedings. They also require that a respondent under the proposed Procedure must, when or before being invited to interview, (i) be given sufficient information to enable her or him to understand the nature of the alleged misconduct, (ii) be notified that he or she does not have to say anything (and that no adverse inferences may be drawn from her or his failure to attend for interview or otherwise participate in the investigation), and (iii) be reminded that he or she is entitled to seek

I6 Grace I of I4 December 20I6. Available at: <https://www.reporter.admin.cam.ac.uk/files/withdrawalgraceiofi4december20I6.pdf $\rangle$ (accessed 2 November 20I7). 
independent legal advice and be provided with sufficient notice of the interview as may reasonably be required to secure such advice.' ${ }^{\text {I7 }}$

That edition of the reporter also established a new Special Ordinance D (v): Precautionary Action (Special Ordinance under Statute D I) with immediate effect, having the effect set out above.

Operating alongside the disciplinary process as set out above, there is now also the involvement of the Office for Student Conduct, Complaints and Appeals (OSCCA). This is the body through which aggrieved students can make a complaint of conduct contrary to the regulations. However, as it has only been established within the past year, it is unclear how it interacts with other elements of the process as it already exists, particularly the role of the Advocate.

\subsection{Sentencing}

As has been set out above, the statutes and ordinances have developed around suitable responses to academic misconduct, not criminal conduct. This can be seen clearly in the sentences available to the DC when it finds 'guilt' through a breach of the regulations. The options available are set out in Special Ordinance D(ii):

'The Discipline Committee may impose the following penalties, either singly or in combination:

(a) deprivation or suspension of membership of the University;

(b) deprivation or suspension of degree, or postponement of, or disqualification from, admission to degree;

(c) deprivation or suspension of the status of Bachelor of Arts;

(d) rustication which is exclusion from residence in the Precincts of the University;

(e) an order to pay compensation;

(f) deprivation or suspension of the right to use University premises or facilities;

(g) any sentence considered by the Discipline Committee to be lighter;

or may, notwithstanding that a person charged has been found to have committed a breach of the general regulations for discipline or other offence against the discipline of the University, resolve not to impose any penalty; provided that any person who is deprived of membership of the University or whose membership of the University is suspended shall thereby suffer deprivation or suspension of all degrees during the continuance of such deprivation or suspension.' (2015, pp. 96-7, paragraph 3)

Unlike in the criminal process, there are no sentencing guidelines. Since 2009, those passing sentences in criminal courts must follow any guidelines applying to the offence unless it is in the interests of justice not to do so (section I25, Coroners and Justice Act 2009). Guidelines are written and reviewed by the Sentencing Council, and the range of offences for which they exist is

I7 Second Joint Report of the Council and the General Board on the consideration of student complaints of harassment and sexual misconduct, University Reporter, University of Cambridge, 25 January 2017. 
broadening, although not without controversy (Ashworth and Padfield, 2015). They also (occasionally) publish guidelines relating to overarching principles (Padfield, 20I6). Furthermore, the DC does not have the benefit of guidance on the purposes of their sentencing exercise. Section I 42 of the Criminal Justice Act 2003 directs a court dealing with an offender to have regard to the need for punishment, the reduction of crime (including its reduction by deterrence), reform and rehabilitation, the protection of the public and the making of reparation by offenders. Should the DC seek to pursue similar purposes? The Septemviri in University Advocate v. Owen Hollands ${ }^{18}$ appeared to accept that it would be appropriate to sentence deterrently, albeit finding (in contrast to the Court of Discipline, the predecessor to the DC) that a deterrent sentence was not called for in the circumstances of that case. Would it be proper for the DC to pursue other purposes in sentencing? Would, for example, it be permissible for the DC to seek through a sentence to protect the reputation of the university? Whilst as a matter of principle, we would argue not, the statutes and ordinances give the DC no guidance.

\section{Other disciplinary bodies - a comparative critique}

An additional basis on which to critique the Zellick approach would be the inconsistency between much of what was advocated and how other institutions that operate their own disciplinary procedures. Whilst space precludes an extensive analysis, it is now trite law that there is nothing inherently improper or unfair in a professional regulator instituting proceedings on the basis of conduct of which the registrant has, in a criminal court, been acquitted. The position was most recently explored in Ashraf v. General Dental Council [2014] EWHC 26I8 (Admin). The Divisional Court (Sir Brian Leveson P. and Cranston J.) rejected the submission that to bring disciplinary proceedings in such circumstances was an abuse of process, noting in particular that the focus of a regulator is to maintain the standards and integrity of a profession, and that this focus is different from those involved in determining whether to prosecute a criminal case. The court also noted the different standard of proof, noting that 'professional conduct panels do not require the criminal standard of proof' (paragraph 33). We consider the court's reasoning applies with similar force to university disciplinary proceedings - the focus of such proceedings is similarly different from the focus of a prosecution. ${ }^{19}$

\section{Practical problems}

The first, and perhaps most concerning, aspect of this addition to the university disciplinary ambit to us as practitioners is the apparent lack of thought that has been given to how the disciplinary process interacts with any police proceedings.

Where a report of a potential offence is made to the police, their first step will usually be to take a statement from the complainant. At this stage, they may also take other statements if there were eyewitnesses to the alleged incident. They will then interview the accused. This might be done following an arrest, or the accused may be invited to attend the police station voluntarily to give their account. Police interviews are carried out under the prescriptive guidance laid down in Police and Criminal Evidence Act I984 ('PACE') Code E, to protect the accused from the risk of coercive police practices. Before any interview is conducted, the accused (or their legal

I8 Available at:〈https:/www.admin.cam.ac.uk/reporter/20II-I2/weekly/6273/Septemviri-Decision.pdf〉 (accessed I4 November 2017).

I9 The Court of Discipline: Practice Statement (Cambridge University Reporter 62 Io, I 9 January 20 I I) states that the procedure is to follow normal adversarial proceedings (para. 29) and the criminal standard and burden apply (para. 30). 
representative) must be given sufficient disclosure of the case against them to enable them to properly answer questions. Such an account will be given under caution, the accused must be advised of their right to free and independent legal advice (Code C, paragraph 6) and the accused may remain silent or provide a prepared statement, though silence brings with it the possibility of an adverse inference being drawn in any later proceedings (as set out under section 34 of the Criminal Justice and Public Order Act I994).

After this, and further investigations if deemed necessary, the police will make a charging decision, usually having obtained advice from a CPS lawyer (Director of Public Prosecutions, 20I3b). In deciding whether to charge, the police and the CPS have to consider a two-element test: first, is there enough evidence to proceed (i.e. sufficient evidence to give rise to a realistic prospect of conviction)? ${ }^{20}$ Second, is there a public interest in bringing the prosecution? This is known as the 'Full Code Test' (Director of Public Prosecutions, 2013a).

If charged, the accused will appear at a magistrates' court within a couple of weeks, at least where they have been released on bail (under Part IV PACE and the Bail Act I976). If they have been refused bail due to conditions set out in Schedule I to the I976 Act being fulfilled, overriding the presumption in favour of bail in section 4, then they are required to be brought before magistrates within twenty-four hours. If the police decide not to charge the accused, then the proceedings will usually cease, although that decision will be subject to review if further evidence becomes available or if the complainant seeks a review of the decision not to prosecute, under the CPS Victim's Right to Review Scheme. ${ }^{2 \mathrm{I}}$ There also remains the possibility that an aggrieved individual will seek to bring a private prosecution if the state does not proceed.

It is at this point, however, that there is potential for significant conflict between the two systems.

Under university disciplinary proceedings, the 'prosecuting' is usually done by a member of university staff - at Cambridge, the UA. This is a post historically held by a lecturer in the Law Faculty, although it is often someone who does not specialise in criminal law. The statutes and ordinances do not require this person to be a legal academic, however, or to have any legal training whatsoever (Statute C, Chapter X): 'The University Advocate shall be a member of the Regent House appointed by Grace on the nomination of the Council.'

When a complaint is made about the conduct of a student to the UA, s/he has a statutory duty to investigate it unless there are specific reasons (set out in the statute) for rejecting it (Special Ordinance $\mathrm{D}(\mathrm{iv}))^{22}$ The importance of this is returned to below - though it is argued that, as the matters are presented before the UA on the basis that they are disciplinary infringements and not criminal offences, the UA is not someone who is 'charged with the duty of investigating offences' for the purposes of PACE. The first stage of such an investigation is usually an investigative meeting'. This is held with the intention that, on hearing the accused's account in it, the UA can decide whether it is appropriate to bring charges against the accused student.

20 It is unclear whether this prospect can be reduced to numbers and, if it can, whether it amounts to $5 \mathrm{I} \%$ or greater, or some other proportion $-R$ (Gujra) v. CPS [2012] UKSC 52.

2 I Available at: 〈http://www.cps.gov.uk/victims_witnesses/victims_right_to_review/〉(accessed 2 November 2017).

22 Special Ordinance D (iv) - 'It shall be the duty of the Advocate to determine whether the person against whom the complaint is made shall be charged and if so before which body; provided that the Advocate shall reject any complaint

(a) if it does not specify the name, and College (if any), of the person against whom it is made; or

(b) if in the Advocate's opinion the evidence presented is not sufficient to enable her or him to decide whether the person should be so charged; or

(c) if in the Advocate's opinion a complaint is vexatious, frivolous, or trivial; or

(d) if in the Advocate's opinion a complaint of grave misconduct is not of sufficiently direct concern to the University to justify its being brought before the University Tribunal.' 
Since the January 2017 amendment to Special Ordinance D, although there are no formal sanctions or adverse inferences detailed for a failure or refusal to engage in this part of the process, it seems that common sense would require that the entire procedure could not be brought to an effective end by the accused student refusing to attend. Therefore, it seems that, in this situation, the UA would have to simply decide from the account given by the complainant whether there was a sufficiency of evidence to proceed.

Investigatory meetings are described to accused students as an opportunity for them to give their side of events. They are warned that the minutes taken at the meeting may be presented as evidence before the disciplinary committee if the matter proceeds. The student is entitled to have someone accompany them to this meeting, and they are advised that the university maintains a panel of people who will accompany the student free of charge should they wish. This list comprises willing volunteers who are lecturers and fellows in law, both in the faculty and at the college level. They receive no payment for acting in this capacity. The vast majority of them are not criminal law specialists, have received no training to be on the panel and do not have any experience of criminal law as practitioners.

The accused student now has to be cautioned. As the meeting minutes can be used as evidence before the disciplinary committee (who are the tribunal that decides guilt on the charge), this is very important. We would observe, however, that even checked minutes are subject to human error, and that the level of protection afforded by handwritten minutes is not akin to that offered by tape recording, as in police interviews. We accept that the practicalities of recording and storing all investigatory meetings are not ideal but, where there is a risk of the first account by the accused student being sought by the CPS in later criminal proceedings, the accuracy of the record of this first account is vital.

As someone advising a student in this position, the terrain is decidedly rocky. If they give a full account in the investigatory meeting, that account will be fully minuted, and the accused student allowed to check and sign those minutes, but it will not be subject to audio recording (as required by PACE Code E, paragraph 3.I, for almost all police interviews in respect of offences triable either way or on indictment), which can be obtained in case of disagreement about what was said. Furthermore, that account is likely to be disclosed to the CPS if police proceedings progress to charge and the student indicates an intention to plead not guilty. It seems likely to the writers that the minutes of the investigatory meeting would be sought by the police or the CPS to obtain the accused student's first account of events. Given that section 29(I) of the Data Protection Act I 998 allows disclosure of personal information for the purposes of the detection of crime and the prosecution of offenders, it is arguable that the university could lawfully disclose this information to the police or CPS without any court order. If the university were to decline to do so voluntarily, it is highly likely that a court would grant an application for an order to produce it. ${ }^{23}$ We note with gladness the observation of the recent Universities UK report (see below) that students must be told that there are circumstances in which information about the matter can be released to third parties (Universities UK, 2016, p. 6).

Furthermore, if this meeting takes place whilst police proceedings are ongoing, there is a risk of crossover. Due to greater pressures on the police, if a complainant reports a matter to both the police and the UA on the same day, the UA is likely to act faster. This means that the investigatory meeting is likely to be held before the accused student has been contacted by the police (indeed, possibly before the accused student even knows that the police had been contacted at all).

Where this account has been given without audio recording, without any clarity about a right to remain silent (or lack thereof), without any sort of warning such as that required by PACE Code C regarding failure to mention relevant facts later relied upon in court and without anyone present

23 Under either section 97 of the Magistrates' Courts Act 1980 or section 2 of the Criminal Procedure (Attendance of Witnesses) Act I965. 
who understands criminal procedure and evidence, prejudice is highly likely. The only possible way to maintain fairness in both sets of proceedings is for the UA to stay proceedings pending the outcome of the police proceedings. At such a point as the police decide to take no further action, or there is a conviction (through plea or trial) or an acquittal, then the university proceedings can properly be reinstated and proceed to their conclusion.

Obviously, where the complainant is pursuing the disciplinary route instead of making a report to the police, there can be no complaint about the UA proceeding straightaway. However, thought must be given to two possible scenarios: first, that the matter may be reported to police by others who hear about it, or witnessed it; and, second, what would happen if the complainant felt aggrieved by the outcome of the university process and decided to make a complaint to the police at that stage - or similarly if the police were alerted to the matter by others. Once again, issues of third-party disclosure orders loom large. At the very least, fairness requires any interviewee to be expressly warned before the commencement of an investigative meeting that the confidentiality of what was said within the meeting could not be guaranteed.

And hanging over all of this is the duality of the role of the UA. Prior to new rules, investigations into matters of university discipline were presided over by the proctors. However, more recently, this part of the proctors' role has been redistributed to the UA, who is consequently both investigating the matter, including conducting an investigative meeting, and then prosecuting the matter. The Royal Commission on Criminal Procedure recognised as far back as I98I the difficulties that arise from alleged criminal acts being investigated and prosecuted by the same body, resulting in the establishment of the CPS to remove the charging and prosecuting function from the police, who investigated offences. The same criticisms apply to the role of the UA, who decides whether to charge a student and then subsequently brings prosecutions and is the university's Advocate in hearings. It is submitted that this means that, however diligently and fairly she acts, they cannot be expected, and certainly cannot be perceived, to be objective when prosecuting a charge that they have brought themselves. Some reassurance might be taken from the fact that there is a review committee examining how to establish a fair process for harassment cases. Whilst superficially reassuring, the committee contains no practitioners, and is of no assistance to students who are investigated under Regulation 6 before it has completed its remit. Furthermore, if the review committee's report leads to positive changes, then those students proceeded against prior to the committee reporting are likely to have been subjected to a substantively different (and possibly less fair) process than those who are proceeded against later.

In general, however, it is concerning that, for now, these newly introduced disciplinary matters have been contorted and shoe-horned into procedures designed only for academic misconduct such as plagiarism. The process is consequently desperately ill-equipped to deal with the needs of complainants, and also the needs of the accused students. It cannot be assumed that accused students will not suffer as a result of such proceedings, even if they are not subsequently charged or found guilty. The regulations give no guidance at all to the UA on the procedure to follow, or how the disciplinary matters may interact with police matters.

Although constrained by space, the authors did seek to establish what the procedures were at other universities that had also been the subject of The Guardian paper. At Oxford, the 'prosecuting' role is taken by the proctors. The scope and remit of their processes are clearly set out in the University Student Handbook (University of Oxford, 20I7b) at section Io. ${ }^{24}$ It is made clear what procedure will be followed in the case of a complaint (paragraph 10.2) and it is emphasised that serious matters will be dealt with by the Student Disciplinary Panel. The process

24 Available at: <https://www.proctors.ox.ac.uk/media/global/wwwadminoxacuk/localsites/proctorsoffice/documents/ Student_Handbook_20I7-I8.pdf> (accessed 8 November 2017). 
to be followed in bringing such a case is set out at paragraph I0.4, and clearly reveals that attention has been paid to the role of due process:

'The Proctors must normally bring a case within six months of first interviewing the student concerned. A student referred to the SDP is sent a formal notice detailing the breaches of regulations alleged, and notifying him or her about a hearing to deal with the case. Before the hearing, the student is given a copy of all the evidence collected by the Proctors and has the opportunity to submit his / her own evidence. The student may be accompanied or represented during the hearing by any person of his or her choice (who need not be legally qualified). Witnesses may be called.'

Further details can be found under the 'Regulations for Disciplinary Investigations by the Proctors under Statute XI' (University of Oxford, 2017a). ${ }^{25}$ This reveals, in sections 2-II, that greater thought has gone into the process that accused students should go through, and the way in which such allegations can be properly investigated. For example, section $7(\mathrm{I})$ requires that the accused student be interviewed, with section 7(3) contemplating that this should be tape recorded and carried out, as far as possible, in accordance with the provisions of PACE I984. Furthermore, the accused student is to be advised at the outset that they do not have to make any comment, but that adverse inferences may be drawn (section IO(I)-(2)). This is a far more transparent process, which is less likely to prejudice the accused student's interests in criminal proceedings, and goes further than even the amendments in the Cambridge process.

As a second comparator, we looked at the University College London guidelines (University College London, 2017). ${ }^{26}$ These contained an entire section on the procedural matters regarding interaction between criminal and disciplinary proceedings (University College London, 20I7, pp. 6-7) and a further section on 'major offences' (including sexual misconduct) (pp. I2-13). The procedure for a hearing is set out (paragraph 70), though, overall, the procedure prior to the hearing is less well defined. There are also no specific stipulations regarding the investigation of such an accusation.

We do not suggest that all the procedures used by the police would be appropriate in the university disciplinary context. Rather, we are concerned that, as the two processes will sometimes overlap, the university process must be formed with its effect on police proceedings considered.

\section{Theoretical considerations}

Our concerns about the way in which universities have formalised the unacceptability of sexual misconduct through rules and regulations do not stop at the procedural. Again, in marked contrast to what is expected from the law, Cambridge's Regulation 6 is poorly drafted for such a serious matter. It is an extremely vague offence seeking to incorporate all violent, sexual and stalking behaviour in one short regulation. Our chief specific concerns are twofold. First, it orders the punishment of behaviour regardless of the mindset of the accused student when they did it. Such a lack of mens rea, usually termed 'strict liability', is largely reserved in English criminal law for regulatory offences, such as many driving offences (e.g. section 4, Road Traffic Act I988; driving, or being in charge, when under influence of drink or drugs), though sexual offences against children also lack a mental element under the Sexual Offences Act 2003. Quite properly,

25 Available at: 〈http://www.admin.ox.ac.uk/statutes/regulations/243-062.shtml〉 (accessed 8 November 2017).

26 Available at: 〈https://www.ucl.ac.uk/srs/academic-manual/cı/disciplinary-code/UCL-Student-DisciplinaryCode-and-Procedure-in-Respec-of-Students.pdf〉 (accessed 2 November 2017). 
in our view, both courts (e.g. in Sweet v. Parsley [1970] AC I32 and, very recently, in Taylor (Jack) [2016] UKSC 5) and legal commentators are very wary of strict liability being used for anything other than regulatory offences (Spencer and Pedain, 2005), citing the Latin maxim of 'actus non facit reum, nisi mens sit rea'. ${ }^{27}$ This is because usually the level of intention is viewed as denoting the levels of culpability, and thus blame. To have sexual misconduct involving two adults punishable outside of the criminal system (where a mental element would be required) regardless of the mindset with which it was done risks punishing individuals disproportionately to their blameworthiness.

Similarly, a great deal of lawful conduct could be 'unwanted and unwarranted'. Indeed, a complainant might not 'want' objectively unobjectionable conduct. Is the line to be drawn purely by reference to the supposed victim's uncommunicated desires? If not, how else is it to be drawn? Such uncertainty about when conduct becomes misconduct is severely damaging to the integrity of the system. Furthermore, the offence applies to sexual behaviour and yet it makes no mention of consent and reasonable belief therein - it simply says the behaviour was 'unwanted and unwarranted' and makes no mention of how that might or might not have been perceived by the accused. Is it the intent of the university to hold students to a higher standard of behaviour in their sexual life than they are held by the criminal law? If so, is this on the basis that the criminal law is merely the lowest acceptable standard of conduct, and it should be open to institutions to require a higher standard? Whilst 'unwanted' is akin to the notion of 'consent' as under section 74 of the Sexual Offences Act 2003, 'the freedom and capacity to consent', the notion of what is unwarranted is, we think, much harder to conceptualise.

Second, there is the objective nature of the offence. A student will be 'guilty' of harassment under Regulation 6 if their behaviour was 'unwanted' and 'unwarranted' (whether they realised that or not) and was 'reasonably likely' to 'violat[e] that other's dignity or (ii) creat[e] an intimidating, hostile, degrading, humiliating, or offensive environment for that other'. 'Reasonably likely' is clearly an objective test. It matters not what the accused student thought or believed or intended by their conduct. If a reasonable person would think it likely (another legally dubious word) that the complainant would experience violation of their dignity or an intimidating, hostile, degrading, humiliating or offensive environment as a result of the accused student's behaviour, then they are guilty under Regulation 6. Use of objectivity is criticised by some, and has been eschewed in some criminal matters, most notably recklessness, due to its likeliness to cause unfairness (e.g. Caldwell [I982] AC 34I; Elliot v. C [1983] I WLR 939; G [2003] UKHL 50) - a position shared by some legal academics (Crosby, 2008). The objective standard does remain an integral part of the law, however; the statutory defence of loss of control (section 54, Coroners and Justice Act 2009) and the construction of 'reasonable belief in consent' in the Sexual Offences Act 2003 are still supported by other academics (e.g. Stark, 20I6, p. 257), who argue that subjectivist arguments are overly simplistic. We are, however, very concerned to find it in such a serious matter.

Third, the reach of the offence is unclear - the regulation's wording is that the conduct is carried out 'within the context of university membership' but, without more on what that means, the construction is very ambiguous. Does the offence cover a member of a university sports' team, who, whilst on a night out in Glasgow during the vacation, wearing his Blues' bowtie, punches someone? Does it cover any member of the university who is within three miles of Great St Mary's Church (the residence requirement for term time) when they commit an act that is unwanted or unwarranted towards any person?

Of course, our criticisms of strict liability and objectivity relate to criminal offences. Although not criminal, it must be remembered when considering this process that any finding of guilt under

27 Though note that strict liability is not regarded as problematic by all. There is also a debate in the literature over what 'actus non facit reum, nisi mens sit rea' was intended to mean by Coke, and others who have since discussed it. 
Regulation 6 will be something many students will have to declare in job applications and, for those studying medicine, for example, it may cause them to be taken before a Fitness to Practise panel. These are not matters without consequence.

The standard of proof that applies before the DC is not set out in either the statutes or the ordinances. ${ }^{28}$ In Holland, the Court of Discipline made findings to the criminal standard of proof, although the reasoned decision of the court gives no explanation for having done so. Whether such an approach is required is open to debate. Following $\operatorname{Re} B$ (Baroness Hale giving the leading opinion), ${ }^{29}$ there is one standard of proof in proceedings outside of criminal courts, even where criminal conduct is alleged, and that standard of proof is the balance of probabilities. The tendency of regulatory bodies, as set out in Ashraf, has been to follow that approach when conducting disciplinary proceedings, and apply the civil standard of proof to allegations of criminal wrongdoing. The regulatory bodies for solicitors and barristers have been notable exceptions, but the Bar Standards Board is currently consulting on lowering the standard of proof and, in a response to that consultation, the Solicitors Regulatory Authority has advocated in favour of the Solicitors Disciplinary Tribunal taking the same approach. ${ }^{\circ}$

Due to space constraints, this paper will not consider the import of human rights on such proceedings, beyond the comment that, when considering such serious matters, it would be outrageous if no protection were afforded. The Septemviri, the University of Cambridge's highest court, has faced that issue before. In Holland, the UA, whilst declining to concede that the university was a public authority for the purposes of section 6(I) of the Human Rights Act I998, accepted that the statutes and ordinances of the university "constitute a species of subordinate legislation and therefore are subject to section 3 of the I998 Act, requiring them to be read and given effect to in a way which is compatible with Convention rights'. ${ }^{\text {I }}$ We wonder whether this was considered when the new Regulation 6 was being drafted.

\section{Universities UK 2016 Report}

In October 2016, Universities UK, in conjunction with Pinsent Masons, published their report on the crossover between criminal and disciplinary proceedings (Universities UK, 20I6). On the whole, the report takes a common-sense approach to difficulties of the sort alluded to above. For example, the report notes that '(Universities') Codes (will need to) include more detailed explanations of the types of behaviour that are unacceptable and indicate how seriously different acts will be treated' (Universities UK, 20I6, p. 2). Our observation on this is that responsibility then rests on the universities to ensure that their Disciplinary Codes are clear, concise and allow students to understand easily what conduct is covered by them. The report continues that the 'Disciplinary Regulations should be followed when determining what action should be taken' and that that procedure should also provide opportunities for the matter to be discontinued if appropriate (Universities UK, 2016, p. 2).

Pains are taken, we are very pleased to see, to emphasise that such cases are difficult, and that the university owes the same duties and obligations to both the accused student and the complainant (Universities UK, 20I6, p. 3), that the welfare of both is paramount (p. 4) and that universities

28 Though see Court of Discipline Practice Direction at para. 30.

29 [2008] UKHL 35.

30 Available at: 〈https://www.sra.org.uk/sra/consultations/consultation-responses/bsb-response.page〉 (accessed 2 November 2017).

3I Available at: 〈https:/www.admin.cam.ac.uk/reporter/20I I-I 2/weekly/6273/Septemviri-Decision.pdf〉 (accessed I4 November 20I7). 
should treat both students fairly and not make any presumptions about either of them (p. 6). The report highlights that the criminal process must always take priority, with any internal process suspended during that time (Universities UK, 2016).

As the police process often takes considerable time (the allegation must be investigated, the suspect interviewed, further investigations arising from that, all before a suspect can even be charged), this suspension of the internal process may outlast the students' time at university if the complaint occurs in a student's final year. ${ }^{32}$ Whilst clearly undesirable, we argue that the risk of prejudicing criminal proceedings, the outcome of which could be lengthy imprisonment in the worst scenarios, is such that this is a risk that must be borne.

\section{Concluding thoughts}

Most young people facing charges in an internal disciplinary procedure will have no experience of being subjected to either criminal or disciplinary systems. The punishments available at Cambridge include the ending of their membership of the university, and consequently their right to study there and receive a degree. Being accused of harassment or sexual misconduct carries huge stress and stigma regardless of the outcome, and such allegations almost always come into the public domain, even if attempts are made to maintain privacy. It is crucial that students who have been subjected to sexual misconduct or harassment are fully supported and have access to a formalised system for reporting the matter if they wish to do so.

However, we are concerned that the actions of some universities in this are demonising the accused students, subjecting them to a potentially unfair, 'hit and miss' process without knowledgeable representation and potential clashes with police matters when the disciplinary outcome can still be very serious. Universities must not lose sight of the fact that all of these processes involve young people who are in times of great transition and need to be dealt with sensitively and fairly, whether they are the complainant or the accused. Whatever pitfalls might be perceived in the criminal justice process (and we do not deny that there are many), there are some matters that internal processes simply are not appropriate to resolve, and we cannot expect them to fill gaps perceived in the criminal justice system.

Professor Graham Zellick himself has recently written openly about the need for better reporting and support procedures for students who are victims of sexual misconduct at university. He called for a mandatory duty on universities to record statistics of sexual violence (McVeigh, 2015). However, he said:

'In my view there have been no legal developments or legislative changes that would require a word of the 1994 report to be modified or rewritten ... It is not to say that there are not other responsibilities laid upon universities in connection with how they handle these matters, but this report dealt with only discipline, dealing with exclusion and suspension of a suspect in an investigation.' (McVeigh, 2015)

32 In a September 2016 report on pre-charge bail, the College of Policing found the mean length of time spent on pre-charge bail to be fifty-three days. However, they found $9 \%$ of suspects were bailed for in excess of ninety days, with rape and sexual offences being one of two core categories of offending making up the majority of offences in which such lengthy periods arose (see <http:/www.college.police.uk/News/College-news/ Documents/Bail report document 439E08I6 2.pdf> (accessed 2 November 2017)). The subsequent implementation of section 63 of the Policing and Crime Act 2017 has theoretically restricted pre-charge bail for police-led investigations, such that any period of bail in excess of twenty-eight days requires the approval of a senior officer and any period in excess of three months requires the approval of the court. However, the general practice of the police has been to seek to circumvent these restrictions by releasing suspects 'under investigation', rather than on bail (see <https://www.norfolk.police.uk/news/latest-news/ suspects-be-'released-under-investigation'-following-home-office-law-changes> (accessed 2 November 2017)). 
So do we think that there is a way that such serious matters can be dealt with under disciplinary structures at all? In part, yes. There are certainly things that could be done that would significantly ameliorate our reservations as criminal lawyers and someone who is used to dealing with university students. In setting out these suggestions, we do not seek to suggest anything other than that those who are the victims of sexual violence should have their dignity and safety protected, and that there should be serious repercussions for perpetrators of such behaviour.

First, we are concerned by the broad and vague nature of the disciplinary offences of harassment that we have looked at. 33 A significant problem occurs because universities seem to have formulated just one offence to cover all behaviour from unwanted texting of a non-sexual nature, or a push in a student union bar, right up to serious physical or sexual violence. We feel strongly that it is not possible to sensibly prohibit such a broad range of actions in one provision, and would encourage universities to examine how they can more clearly formulate these provisions.

Second, whilst recognising that these are not criminal offences, we would ask universities to examine the mental element with which the prohibited behaviours have to be done for them to fall under the auspices of disciplinary structures. The presence of objectivity, strict liability and 'likelihood' all in one regulation has the effect of making the threshold for punishable behaviour both very low and, potentially in some fact patterns, unintentional. For policies aimed at university students, it is also regrettable that there is no clear indication of the effect of intoxication on culpability, such as Majewski tries to provide in criminal law. ${ }^{34}$ Such mental elements were reflected across the policies we looked at.

Third, the punishment structures in place need to be considered. They have largely been formulated to deal with academic misconduct. They are not suited to such serious matters. There are no guidelines, creating a serious risk of disparity between cases.

Fourth, we are of the strong opinion that internal proceedings should never be brought until police proceedings are concluded. We maintain that this must be an absolute rule if we are to uphold any sense of accused students being innocent until proven guilty. This was recognised by a number of institutions in their guidelines on dealing with harassment.

Finally, and relating to all of the above, we are concerned about the lack of knowledgeable support and representation for accused students. Whilst they might have access to student union or Junior Combination/Common Room (JCR) representative, counselling assistance and tutorial support, those avenues are unlikely to be able to offer any substantive guidance on the process. Most policies allowed a student to have someone with them in formal meetings, but did not

33 Oxford has the same definition of harassment as Cambridge - see section 6 of the Oxford University 'University Policy and Procedure on Harassment' (2014) (available at: 〈https://www.admin.ox.ac.uk/eop/ harassmentadvice/policyandprocedure/> (accessed 2 November 2017)). However, in sections IO-I5, there is then further elucidation of what might and might not amount to harassment. This is detail sadly missing from the Cambridge documents. Meanwhile, UCL seem to have eschewed a fixed definition in favour of setting out the 'spirit' of harassment through examples of types of incidents that would amount to such behaviour (see 〈https:/www.ucl.ac.uk/current-students/guidelines/harassment-bullying〉 (accessed 2 November 2017)). Durham University sets out its definition in its 'Respect at Study Policy and Code of Practice and Procedures for Students to Make a Complaint about Harassment' (available at: <https://www. dur.ac.uk/university.calendar/volumei/codes of practice/> (accessed 2 November 20I7)): 'Harassment is unwanted conduct which causes an individual to experience alarm or distress.... The key is that the actions or comments could reasonably be viewed as being hostile or intimidating, demeaning and unacceptable to the individual, and likely to cause them alarm or distress....

Harassment may have either the purpose or the effect of violating an individual's dignity or create an intimidating, hostile, degrading, humiliating or offensive environment for that individual.'

34 DPP v. Majewski [I 977] AC 443 - this case set out how a judge should direct a jury about the mental element of an offence committed when the defendant was intoxicated (through drink or drugs). For many offences of 'basic intent', intoxication provides no defence. For most 'specific intent' offences, the defendant can argue that they were unable to form the mental element required for the offence because they were drunk. 
consider what experience this person should or could have. Guidance on the substantive process, and particularly its interaction with criminal proceedings, will be of particular importance where a report is made to the police, even if criminal proceedings do not progress as far as charge. At Cambridge, there is a panel of defence advocates, all of whom lecture or supervise in some area of law. All agree to represent students accused of disciplinary infractions for free. And, whilst 'disciplinary matters' equated to academic misconduct, this posed no problems. However, when there is the thorny problem of trying to protect an accused's interests in disciplinary proceedings that are being run alongside criminal proceedings by individuals who have no knowledge of how criminal procedure works, someone with knowledge of both criminal law and procedure becomes a much more necessary tool.

There is no legal aid available for disciplinary matters, as they are non-criminal. And yet it can be expected that a serious disciplinary case will require a conference with the accused student, presence at the investigatory meeting, further meetings if necessary and potentially representation before the UDP if the case progresses that far. In unfair means cases, it was standard (and perfectly proper) practice to have a short meeting; the student usually pleaded guilty at the hearing, and mitigation was advanced. In more sensitive matters that is not sufficient. If universities anticipate many of these claims being brought (and it seems likely to us that the combination of alcohol and young people alone means that there will be a not insignificant number), they need to consider how to ensure that accused students are properly represented, in the same way as they must ensure that complainant students are properly supported. This may mean retaining a panel of practitioners who are willing to act pro bono so that none is called upon too often, or creating an office with a small stipend that is the opposite number to the UA (a University Defender, possibly?). If the university sees a high number of Regulation 6 cases being investigated, it may quickly become impossible for the Advocate herself to manage the case-load around her own academic commitments. The possibility of standing counsel in both prosecution and defence roles should, we argue, be seriously considered. In April 2017, the university indicated that it would not provide further assistance to accused students and that, if no one from the panel was willing and available to represent the student, then they would have to pay privately for counsel, or go without representation. It is concerning that whether a student is represented in this quasicriminal process will come down to the number of other cases ongoing (wholly outside of their control) and their financial means.

We have argued that there are currently three main barriers to fairness in university proceedings for sexual misconduct. Until the offence is clearly defined, there are sufficient numbers of appropriately trained personnel to both bring the cases and defend them, and the rights of the accused are taken seriously and protected within the process, universities should not be attempting to deal with this sort of behaviour. To do so compromises universities' undeniable duties to protect the welfare of all students, both complainants and accused.

\section{References}

ashworth, A. and padfield, N. (2015) 'Five Years of the Sentencing Council', Criminal Law Review 9: $657-658$.

вошсотт, O. (2015) 'Student Sues Oxford over Handling of Rape Complaint', The Guardian, 7 May. CRosBy, C. (2008) 'Recklessness - the Continuing Search for a Definition', Journal of Criminal Law 72 (4): 3I $3-334$

DiReCtOR OF PUblic prosecutions (2013a) Code for Crown Prosecutors, 7th edn. London, Crown Prosecution Service.

DIRECTOR OF PUbliC PROSECUTIONS (2013b) The Director's Guidance on Charging, 5th edn (revised arrangements). London: Crown Prosecution Service. 
FISHER, B.S., DAIGLE, L.E., CULLEN, F.T. and tuRner, M.G. (2003) 'Reporting Sexual Victimization to the Police and Others: Results from a National-Level Study of College Women', Criminal Justice and Behavior 30(I): 6-38.

GOLDHILL, O. and WARD, V. (2015) 'Ex Student Sues Oxford University over Rape Claim', The Guardian, 7

May. Available at: 〈http://www.telegraph.co.uk/women/womens-life/I I 586429/Ex-student-sues-

Oxford-University-over-rape-claim.html $>$ (accessed 2 November 2017).

horgan, A. (20I5) 'Hold Your Horses - One Policy Change Doesn't Mean We've Won on Sexual

Harassment', The Cambridge Student, 7 August. Available at: 〈http:/www.tcs.cam.ac.uk/comment/ o034385-hold-your-horses-one-policy-change-doesn-t-mean-we-ve-won-on-sexual-harassment.html > (accessed 2 November 2017).

mCveigh, K. (2015) 'Universities Should Have to Record Sexual Violence Claims, Says Expert', The Guardian, 25 October.

MCVEIGH, K. and CRESCI, E. (20I5) 'Student Sexual Violence: "Leaving Each University to Deal With It Isn't Working”', The Guardian, 26 July.

midgley, S. (1994) 'College "Made Errors in Rape Case”: King’s Rules Were Probably Flawed in

Principle, Inquiry Finds', The Independent, I I February.

national Union of StUdents (nus) (2015) How to Respond to Complaints of Sexual Violence: The Zellick

Report. London: National Union of Students. Available at: 〈https://nusdigital.s3-eu-west-I. amazonaws.com/document/documents/_9993/NUS_Zellick_report_briefing_pdf〉 (accessed 2 November 2017).

PADFIELD, N. (2016) ‘Guidelines Galore’, Criminal Law Review 5: 30I-302.

SPENCER, J.R. and PEDAIN, A. (2005) 'Approaches to Strict and Constructive Liability in Criminal Law' in A. Simester (ed.) Appraising Strict Liability. Oxford: OUP.

stark, F. (2016) Culpable Carelessness: Recklessness and Negligence in the Criminal Law. Cambridge:

Cambridge University Press.

UNIVERSITIES UK (2015) UUK Taskforce on Violence against Women, Harassment and Hate Crime: Summary

Note of First Meeting. London: Universities UK.

universities UK (2016) Guidance for Higher Education Institutions: How to Handle Alleged Student Misconduct Which May Also Constitute A Criminal Offence. London: Universities UK. UNIVERSITY COLLEGE LONDON (20I7) UCL Academic Manual. London: UCL. UNIVERSITY OF OXFORD (2017a) Statutes and Regulations, Regulations for Disciplinary Investigations by the Proctors under Statute XI, Council Regulations 2 of 2006. Oxford: University of Oxford. UNIVERSITY OF OXFORD (20I 7 b) The University Student Handbook. Oxford: University of Oxford Academic Administration Division Communications.

upHAm, T. (2015) 'Cambridge University Changes Tack on Sexual Assault Guidelines', The Cambridge Student, I August. Available at: 〈http://www.tcs.cam.ac.uk/news/0034378-cambridge-universitychanges-tack-on-sexual-assault-guidelines.html〉 (accessed 2 November 2017). 